\title{
Fossil calibration dates \\ for molecular phylogenetic analysis of snakes 2: Caenophidia, Colubroidea, Elapoidea, Colubridae
}

\author{
Jason J. Head, Kristin Mahlow, and Johannes Müller
}

\begin{abstract}
Caenophidia, the snake clade that includes the highest species richness, morphological diversity, and ecological breadth within Serpentes, has been extensively studied with respect to molecular phylogenetic systematics. The majority of the caenophidian fossil record, though dense, has been taxonomically defined on the basis of general anatomical similarity or shared geographic provenance with extant reference taxa. As a result, historical patterns of diversification within the clade are poorly constrained due to a paucity of reliable fossil calibration dates. Here we provide 10 fossil calibration dates for phylogenetic analysis of caenophidian relationships. Calibration points include apomorphy-based systematic justifications based on cranial and precloacal vertebral elements and precise dates for hard minimum divergence timings. Calibrated nodes are for Caenophidia, Acrochordus, Elapoidea, Colubridae, and constituent subclades. Hard minimum divergence timings range from late Cretaceous to Miocene. The spatial and temporal distribution of reliable first occurrence of colubroid taxa suggests late Paleogene intercontinental dispersals between Asia, North America, and Africa, followed by rapid diversification and subsequent dispersals into all non-Polar continents by the early Neogene.
\end{abstract}

Jason J. Head. Department of Zoology and University Museum of Zoology, Downing St., University of Cambridge, CB2 3EJ, England jjh71@cam.ac.uk

Kristin Mahlow. Museum für Naturkunde, Leibniz-Institut für Evolutions- und Biodiversitätsforschung, Invalidenstr. 43, D-10115 Berlin, Germany Kristin.Mahlow@mfn-berlin.de Johannes Müller. Museum für Naturkunde, Leibniz-Institut für Evolutions- und Biodiversitätsforschung, Invalidenstr. 43, D-10115 Berlin, Germany Johannes.Mueller@mfn-berlin.de

Keywords: Serpentes; fossil; calibration; Caenophidia; Colubroidea; Elapoidea; Colubridae

Submission: 13 January 2016 Acceptance: 16 May 2016

PE Article Number: 19.2.9FC

Copyright: Palaeontological Association June 2016

Submission: 13 January 2016. Acceptance: 16 May 2016

Head, Jason J., Mahlow, Kristin, and Müller, Johannes. 2016. Fossil calibration dates for molecular phylogenetic analysis of snakes 2 : Caenophidia, Colubroidea, Elapoidea, Colubridae. Palaeontologia Electronica 19.2.2FC: 1-21

palaeo-electronica.org/content/fc-9

Calibrations published in the Fossil Calibration Series are accessioned into the Fossil Calibration Database (www.fossilcalibrations.org). The Database is a dynamic tool for finding up-to-date calibrations, and calibration data will be updated and annotated as interpretations change. In contrast, the Fossil Calibration papers are a permanent published record of the information on which the calibrations were originally based. Please refer to the Database for the latest data. 


\section{INTRODUCTION}

The vast majority of extant snake diversity is contained in Caenophidia, a clade consisting of > 2500 species (Vidal et al., 2009). Caenophidia was originally erected by Hoffstetter (1939) to include snakes more derived than "henophidian grade" taxa, considered at the time to include boids and anilioids. Morphological studies recognized a close relationship between relationship between Colubroidea, itself consisting of viperids, colubrids, elapids, homalopsids, and other "derived snakes", and Acrochordus, the genus of file snakes, wart snakes, and elephant trunk snakes (e.g., Bellairs and Underwood, 1951), with explicit morphological phylogenetic analyses recovering a sister-taxon relationship between the two (e.g., Rieppel, 1988; Kluge, 1991; Cundall et al., 1993; Lee and ScanIon, 2000; Tchernov et al., 2000).

Numerous molecular phylogenetic studies of caenophidians have subsequently been conducted. Research foci associated with these analyses include molecular divergence timing estimates, biogeographic histories, diversification patterns, and the evolution of toxic venoms, making them the most intensely studied squamate clade with respect to molecular phylogenetics (e.g., Keogh, 1998; Burbrink et al., 2000; Gravlund et al., 2001; Burbrink, 2002; Vidal, 2002; Fry et al., 2003; Kelly et al., 2003; Keogh et al., 2003; Nagy et al., 2003; Pinou et al., 2004; Lawson et al., 2005; Lukoschek and Keogh, 2006; Burbrink and Lawson, 2007; Vidal et al., 2007; Fry et al., 2008; Sanders et al., 2008; Hedges et al., 2009; Kelly et al., 2009; Pyron and Burbrink, 2009a,b,c; Zaher et al., 2009; Burbrink and Pyron, 2010; Sanders et al., 2010; Vidal et al., 2010; Murphy et al., 2011; Pyron et al., $2013 a, b)$. The majority of studies have recovered the same sister-taxon relationship between Acrochordus and taxa traditionally included in Colubroidea (but see Pyron et al., 2013a for an alternate hypothesis of sister-taxon relationships of Acrochordus).

The caenophidian fossil record has been more thoroughly documented than for any other squamate clade, with a few Late Cretaceous to early Paleogene records primarily, but not exclusively, from southern continental landmasses (e.g., Rage, 1975; Rage, 2008; Rage et al., 1992; Rage and Werner, 1999; Rage et al., 2008; Rage et al., 2013; Parmley and Holman, 2003; Head et al., 2005) and hundreds of records from the late Paleogene to Holocene of mainly North America and Europe (e.g., Rage, 1984[and references therein]; Szyndlar, 1984, 1985, 1987, 1991a, 1991b, 2012;
Szyndlar and Schleich, 1993; Szyndlar and Rage, 1999; Holman, 2000 [and references therein]; Ivanov, 2000, 2002; Ivanov and Böhme, 2011), as well as records from South America, Africa, and Asia (e.g., Albino, 1996; Albino and Montalvo, 2006; Rage, 1973, 1976, 2003; Rage and Ginsburg, 1997; Rage and Danilov, 2008; Head, 2005, Head et al., 2006; Head et al., 2007; Head and Bell, 2008). The published record has been used to calibrate multiple caenophidian molecular phylogenies (e.g., Noonan and Chippindale, 2006; Burbrink and Lawson, 2007; Wüster et al., 2007, 2008; Alfaro et al., 2008; Sanders and Lee, 2008; Sanders et al., 2010; Kelly et al., 2009; Lukoschek et al. 2012; Pyron and Burbrink, 2012), with different fossils employed to produce highly disparate divergence estimates (Lukoschek et al., 2012).

There are multiple problems with calibrating molecular phylogenies using the published literature on fossil snakes (Head, 2015), especially for caenophidians: The absence of discrete apomorphies in vertebral morphology for most taxa limits testable, reproducible taxonomic hypotheses from isolated fossils. Additionally, considerable intracolumnar, individual, and ontogenetic variation exists in vertebral morphology, and very few studies have attempted to examine the influence of these factors in taxonomic assignments (Szyndlar, 2012 [but see Szyndlar, 1984 and LaDuke, 1991a for analyses of intracolumnar and individual variation]).

Because of these potential limitations, identity of snake fossils has traditionally relied on a generalized "vertebral form taxonomy" that uses overall, often proportional, shape to recognize taxa and implicitly does not follow a phylogenetic taxonomy, despite using the same taxon names (see Szyndlar et al., [2008] and Szyndlar, [2012] for discussion). Other approaches include general similarity/ "gestalt" approaches (see Hecht and LaDuke, 1997 for discussion), unsupported authority statements, and the geographic provenance of extant taxa (e.g., Holman, 2000[and references therein]), which results in circularity in reconstructing temporal and spatial histories of extant clades (Bell et al., 2004; Bell et al., 2010). The caenophidian record does not lack utility, however. Diagnostic vertebral characters are observable (e.g., Hoffstetter and Gasc, 1969; Slowinski, 1994; Sheil and Grant, 2001, Head, 2005), and cranial remains are preserved for several key taxa.

Here we provide fossil calibrations for multiple caenophidian clades based on observable apomorphies. We restrict calibrations to taxa represented by either diagnostic cranial remains or 
vertebrae that can be diagnosed by discrete characters or unique character combinations. Using this approach, we are only able to recognize 10 extant caenophidian taxa relative to the many dozens recognized by the aforementioned methods, but our calibrations are testable observations that allow analysis of systematic, ecological, and biogeographic hypotheses of extant caenophidians because their phylogenetic justifications are independent of the histories of those taxa. There are two published comprehensive molecular phylogenies of Caenophidia that can be used as scaffolds for node calibration (Pyron et al., 2013a, b). We use the topology of Pyron et al. (2013a) because it includes greater taxonomic and sequence sampling, but additionally consider the topology of Pyron (2013b) where appropriate.

\section{Institutional Abbreviations}

BSP, Bayerische Staatssammlung Für Paläontologie Und Historische Geologie, Munich; H-GSP, Harvard-Geological Survey of Pakistan; Islamabad, Pakistan; MCZ, Museum of Comparative Zoology, Harvard University, Massachusetts, U.S.A.; MGT, Université Montpellier; MNHN, Muséum National d'Histoire Naturelle, Paris, France; QM F, Queensland Museum, Queensland, Australia; UCBL, Université Claude Bernard, Lyon; UNSM, University of Nebraska State Museum, Nebraska, U.S.A. VAS, "R.S. Rana collection from Vastan" (Rage et al., 2008); Vb, the abbreviation "Vb" is not defined in Rage and Werner (1999); however, specimens labeled with "Vb" and field numbers were reported to be "...curated at the fossil collection of the Technical University of BerlinSpecial Research Project 69..." (Rage and Werner, 1999: 87), and are now housed in the Museum für Naturkunde Berlin.

\section{CALIBRATIONS}

\section{(1) Pan-Caenophidia}

Node Calibrated. Divergence between the total clade of Caenophidia and its nearest crown sister taxon, Booidea (sensu Head, 2015).

Fossil Taxon. Krebsophis thobanus (Rage and Werner, 1999).

Specimen. Vb-681, incomplete precloacal vertebra.

Additional Materials. Six precloacal vertebrae.

Phylogenetic Justification. Krebsophis thobanus is unambiguously included within
Russellophiidae on the basis of brief, ventrolaterally angled articular facets of the prezygapophyses and compressed prezygapophyseal buttresses that form a vertical ridge, as well as more ambiguously by an elevated posterior neural arch (Rage and Werner, 1999). Characters that unite Russellophiidae, including Krebsophis, with Caenophidia include a highly elongate centrum, relatively small, circular cotyle and condyle, and well-developed subcentral paralymphatic channels defining the lateral margins of a distinct haemel keel.

Minimum Age. $66 \mathrm{Ma}$, latest Maastrichtian.

Maximum Age. 72.1 Ma, latest Campanian to earliest Maastrichtian.

Age Justification. Krebsophis thobanus was recovered with a taxonomically diverse snake fauna from the Wadi Abu Hashim member of the Wadi Milk Formation of Sudan (Werner and Rage, 1999). The Wadi Milk Formation was considered Cenomanian based on palynological (Schrank,1990; Schrank and Awad, 1990) and fish data (see Werner and Rage, 1999). However, the snake fauna of Wadi Abu Hashim is much more biostratigraphically consistent with a Maastrichtian age assignment: Nigerophiids and large-bodied madtsoiids are only present in Maastrichtian sections of Madagascar and India (e.g., Prasad and Rage, 1995; Rage et al., 2004; LaDuke et al., 2010; Mohabey et al., 2011; Pritchard et al., 2014), the oldest record of palaeophiids is from the Maastrichtian of Morocco (Rage and Wouters, 1979), the oldest aniliid anatomically consistent with "Coniophis" from Wadi Abu Hashim is Australophis from the late Campanian-Early Maastrichtian of Argentina (Goméz et al., 2008, see Head [2015] for discussion of the age of Australophis), and anatomically similar "Coniophis" is known from the Maastrichtian of India (Rage et al., 2004). Referral to two snake specimens from Wadi Abu Hashim to Early Cretaceous "lapparentophiid-grade snakes" by Rage and Werner (1999) was admittedly based solely on plesiomorphic characters, which are taxonomically uninformative. A Cenomanian age for madtsoiids, nigerophiids, palaeophiids, and "Coniophis" form taxon aniliids would represent at least 
20 million year range extension for all, of which there is no additional unambiguous evidence. Additionally, the Shendi Formation of Sudan, which shares a vertebrate fauna with the Wadi Milk Formation (J.M. pers. obs.) and previously considered a lateral extension of the Wadi Milk, has recently been dated as Campanian-Maastrichtian (Salih et al., 2015). Based on ages of comparable snake faunas from other Gondwanan landmasses and the age estimates for the Shendi Formation, we assign an age range for Krebsophis based on minima for the Campanian and Maastrichtian (Ogg et al., 2012).

Discussion. The systematic relationships of russellophiids are poorly constrained. Russellophis tenius was originally considered a primitive caenophidian by Rage (1975) on the basis of small prezygapophyseal accessory processes and synapophyseal morphology that is anatomically consistent with "henophidian" taxa. Subsequent records have been placed either within only Caenophidia ("?Russellophiidae" Rage, 2008), or Colubroidea within Caenophidia (e.g., Rage et al., 2008). Explicit character support for inclusion of Russellophiidae within the colubroid total clade has not been provided, but a testable hypothesis for the interrelationships of the clade is required to calibrate Caenophidia and potentially Colubroidea. Russellophiids share an elongate centrum with colubroids to the exclusion of Acrochordus, however, they lack vertebral synapomorphies of crown Caenophidia, including: well-developed prezygapophyseal accessory processes, well-differentiated paraand diapophyseal articular facets of the synapophyses, and pleurocentral hypapophyses present throughout the precloacal vertebral column. Due to these character distributions, placement of Russellophiidae within Colubroidea cannot be supported, and the fossil record of the clade can only calibrate the caenophidian total clade.

\section{(2) Pan-Colubroidea}

Node Calibrated. Divergence between the total clade of Colubroidea and its nearest crown sister taxon, (Acrochordus+Xenodermatidae).
Fossil Taxon. Procerophis sahnii (Rage et al., 2008).

Specimen. VAS 1014, posterior trunk vertebra.

Additional Materials. Five precloacal vertebrae, two caudal vertebrae.

Phylogenetic Justification. Procerophis is assigned to Colubroidea on the basis of: elongate, narrow centrum and neural arch, paracotylar foramina, and an anteroposteriorly elongate neural spine that possesses a uniform width along its length.

Minimum Age. $50.5 \mathrm{Ma}$, middle Ypresian. Maximum Age. $72.1 \mathrm{Ma}$, earliest Maastrichtian.

Age Justification. Procerophis was recovered from a diverse snake fauna in the Cambay Formation, Gujarat, India. The Cambay Formation is minimally dated based on the occurrence of the planktonic foraminifera taxon Nummulities burdigalensis burdigalensis, which corresponds to Shallow Benthic Zone 10 (lower Cuisian, Serra-Kiel et al., 1998). SBZ 10 corresponds to planktonic foraminiferal zone $\mathrm{P} 6 \mathrm{~b}$, which is middle Ypresian, approximately 53-50.5 Ma (Vandenberghe et al., 2012). Maximum age is for the early Maastrichtian based on the first occurrence of Caenophidia from the Wadi Milk Formation (Werner and Rage, 1999).

Discussion. Among extant colubroids, these characters are characteristic of colubrines. However, Procerophis possesses a plesiomorphic prezygapophyseal morphology (Rage et al., 2008), including prezygapophyseal articular facet long axis predominately anteriorly angled, and small accessory processes. Additionally, the haemal ridge is poorly differentiated from the ventral surface of the central body, unlike crown colubroids.

Thaumastophis missiaeni, also from the Cambray Formation, similarly lacks a hypapophysis, and the majority of vertebral morphology is consistent with assignment to Colubroidea. However, the taxon possesses vertical, blade-like prezygapophyseal accessory processes, which are otherwise apomorphic for Acrochordus. As a result, the taxon is here considered Caenophidia indeterminate, following Rage et al. (2008). 
Russellophis crassus, also from the Cambay Formation, is a potential alternate anchor taxon for the Pan-Colubroidea divergence. As previously noted, however, the systematic relationships of russellophiids relative to either the caenophidian crown or the colubroid total clade are poorly constrained. Colubroid characters including an elongate, narrow neural spine of a uniform transverse width that extends from the zygosphene to the posterior median notch of the neural arch, paracotylar foramina, comparatively well-developed prezygapophyseal accessory processes, and potentially well-differentiated dia-and parapophyseal articular facets, are present in Procerophis but absent in russellophiids (e.g., Rage, 1975; Rage and Werner, 1999; Rage, 2008), indicating that Procerophis is the most appropriate minimum divergence point for the colubroid total clade.

\section{(3) Acrochordus javanicus}

Node Calibrated. Divergence between Acrochordus javanicus and ( $A$. ararfurae+A. granulatus).

Fossil Taxon. Acrochordus dehmi (Hoffstetter, 1964).

Specimen. H-GSP 41555, two precloacal vertebrae.

Additional Materials. Five precloacal vertebrae, two caudal vertebrae.

Phylogenetic Justification. Acrochordus dehmi is hypothesized to be the sister taxon to $A$. javanicus to the exclusion of $A$. arafurae or $A$. granulatus on the basis of parazygosphenal foramina located just ventrolaterally to the base of the zygosphene on the anterolateral surface of the neural arch (Head, 2005; Sanders et al., 2010). Acrochordus dehmi is placed within the genus Acrochordus on the basis of ventrally elongate and pendant synapophyses, hemispherical, vertically oriented and blade-like prezygapophyseal accessory processes, and multiple paracotylar foramina (Hoffstetter, 1964; Head, 2005).

Minimum Age. 18.05 Ma.

Maximum Age. $23.03 \pm 0.05 \mathrm{Ma}$, earliest Aquitanian, earliest Miocene (Hilgen et al., 2012).

Age Justification. The minimum age is based on dating of locality Y846 from the
Kamlial Formation of the Siwalik Group on the Potwar Plateau of Pakistan, which is the oldest record of Acrochordus dehmi (Head, 2002, 2005). The maximum age follows Head et al. (2007) based on the first occurrence of the genus from the Aquitanian Kharinadi Formation, Gujarat, India.

Discussion. Bayesian molecular divergence estimates for Acrochordus javanicus from ( $A$. arafurae $+A$. granulatus) based on the calibration points cited here model a divergence of $20.3 \mathrm{Ma}$ with a range of 6.6-34.0 Ma (95\% highest posterior density values) (Sanders et al., 2010). The fossil record of Acrochordus also constrains the divergence timing of Xenodermatidae following Pyron et al. (2013a); however, xenodermatids are more closely related to colubroids than Acrochordus in the topology of Pyron et al. (2013b).

\section{(4) Viperinae}

Node Calibrated. Divergence between total clades Crotalinae+Viperinae

Fossil Taxon. "Vipera aspis complex" (Szyndlar and Rage, 1999).

Specimen. MNHN SG 13732, precloacal vertebra.

Additional Materials. MNHN SG 13733, posterior precloacal vertebra (Szyndlar and Rage, 1999).

Phylogenetic Justification. Assignment to Viperidae is based on a large, elongate, straight, and posteroventrally angled hypapophyses, laterally short prezygapophyseal accessory processes, large cotyle and condyle, low and flattened posterior neural arch, and elongate, anteroventrally angled parapophyseal process (sensu Head, 2005) (Szyndlar, 1991b; Szyndlar and Rage, 1999). Assignment to Viperinae relative to Crotalinae is based on the presence of low neural spines, which is restricted the "aspis complex: of extant European viperines (e.g., Szyndlar, 1984, 1991b, Szyndlar and Rage, 1999).

Minimum Age. 20.0 Ma, youngest age for MN2 (Agustí et al., 2001).

Maximum Age. 23.8 Ma (Agustí et al., 2001), oldest age for MN1 (see below).

Age Justification. The minimum age is for the youngest age for Neogene Mammal (MN) Biochron 2, based on the age of the 
St-Gérand-le-Puy complex (Szyndlar and Rage, 1999, 2001). The youngest absolute age for MN2 is poorly constrained, but at minimum age of $20.0 \mathrm{Ma}$ is estimated, based on correlation of the oldest MN3 fossil localities with Geomagnetic Polarity Timescale (GMPT) chron C6n (Agustí et al., 2001). Many St-Gérand-le-Puy localities are within MN 2a (e.g., Göhlich et al. 2005). If the St-Gérand-le-Puy viperid fossils are from these localities, then the minimum age would be slightly older at the top of GMPT chron 6AAn, dated to approximately $21.8 \mathrm{Ma}$ (Sen, 1997 after Agustí et al., 2001). The maximum age is for the base of MN 1, the age of the oldest viperid fossil from Weisenau, Germany (Szyndlar and Böhme, 1993; Szyndlar and Rage, 1999, 2002).

Discussion. Viperids possess a distinct vertebral morphology that includes a straight, elongate, and posteroventrally oriented hypapophysis that is present throughout the prelcoacal vertebral column, strongly depressed neural arches, extremely elongate parapophyseal processes, relatively short prezygapophyses with short, blunt accessory processes, and large cotyle-condyle articulations. An anatomical distinction has been made between the "oriental vipers" (composed of species of the subgenus Montivipera and the Macrovipera) and the "Vipera aspis complex (composed of primarily $V$. aspis and $V$. ammodytes) based on small size, elongate centra and short neural spines in the latter complex (Szyndlar and Rage, 1999). Among extant taxa, these characters do distinguish the "aspis complex" species from other taxa, but there are no other vertebral characters that differentiate the majority of other viperine taxa from crotalines. As a result, the record described from the St-Gérand-le-Puy complex represents the oldest definitive viperine fossil record. The oldest records of viperids are from Weisenau (Szyndlar and Böhme, 1993) and the Harrison Formation of Nebraska (Holman, 1981), and predate the " $V$. aspis complex) by up to four million years. However, the identities of these records as either stem viperids, crown viperines, and/or crown crotalines cannot be unambiguously determined from verte- bral characters. These record do not minimally calibrate the divergence of viperids, as they are predated by the first occurrence of the viperid sister taxon (see below). The oldest unambiguous crotaline fossil record consists of two maxillae from the late Miocene of Ukraine (Ivanov, 1999), and is much younger than the viperine record we cite to calibrate the viperine-crotaline divergence.

\section{(5) Colubridae+Elapoidea}

Node Calibrated. Divergence of crown colubroid lineages.

Fossil Taxon. Coluber cadurci Rage, 1974.

Specimen. MGT 3505 precloacal vertebra (holotype).

Additional Materials. MGT 3506, caudal vertebra, "plusieurs vertèbres dorsales et caudales" (Rage, 1974:295).

Phylogenetic Justification. Assignment to (Colubridae+Elapoidea) is based on the presence of: a well-developed, narrow haemel keel that is uniform in transverse width and extends from an expanded cotylar ventral lip anteriorly to terminate posteriorly just anterior to the condyle; epizygapophyseal spines, and; elongate prezygapophyseal accessory processes (Rage, 1974).

Minimum Age. $30.9 \pm 0.1 \mathrm{Ma}$

Soft Maximum Age. Indeterminate.

Age Justification. The minimum age is based on the age of the type locality at Mas de Got A, which is correlated to Paleogene Mammal (MP) biochron 22. MP 22 ranges from $32.6 \pm .1 \mathrm{Ma}$ to $30.9 \pm .1$ Ma (Schmidt-Kittler, 1987; İslamoğlu et al., 2006; Szyndlar, 2012; Rage, 2006; Augé and Rage, 2014).

Discussion. Referral of Coluber cadurci to the total clade (Colubridae+Elapoidea) is unambiguously supported by the aforementioned character combination. The presence or absence of ventral hypapophyses throughout the precloacal vertebral column has traditionally been used to distinguish Colubrinae from Natricinae and/or Elapidae (Bell et al., 2003; Szyndlar, 2012), and was used in the original taxonomic assignment of $C$. cadurci (Rage, 1974); however, absence of continuous precloacal hypapophyses occurs in numer- 
ous elapoid and dipsadine taxa in addition to Colubrinae (Dowling and Duellman, 1978 after Pyron et al., 2013), and the character cannot diagnose colubrines to the exclusion of other clades. Similarly Coluber cannot be diagnosed on the basis of vertebral morphology (Szyndlar, 2012), and referral to the genus has been subsequently recognized as non-phylogenetic (Rage, 1988:468). The morphology of the haemal keel in $C$. cadurci is consistent with colubrids and elapoids that similarly lack a hypapophyses, and is distinct from the morphology of the keel in russelophiids and more basal snakes in which the keel is often wide and more poorly defined (Head, 2015). As a result, Coluber cadurci provides a calibration for the total clade of (Colubridae+Elapoidea) but cannot constrain divergences within the clade.

Natrix mlynarskii is approximately coeval with C. cadurci, and was assigned to Natrix based on general resemblances with modern and fossil species of genus (Rage, 1988). The type specimen of $N$. mlynarskii is too incomplete for unambiguous referral to Natrix, but appears to possess a distinct, short hypapophysis similar to natricines, some dipsadines, and most elapoids. The records of Coluber cadurci and Natrix mlynarskii predate the oldest definitive records of elapoids from the late Oligocene by approximately $6 \mathrm{Ma}$ (McCartney et al., 2014).

Older colubroid records that have been referred to Colubridae or constituent subclades extend into the early Paleogene of Asia and North America (Rage et al., 1992; Parmley and Holman, 2003). However, these records are too incomplete to distinguish from stem Colubroidea and are therefore uninformative with respect to divergence of the (Colubridae+Elapoidea) total clade. Similarly, additional records referred to Colubroidea from the Eocene of Africa and South Asia (Rage et al., 2003, 2008; Head et al., 2005; McCartney and Seiffert, 2015) demonstrate the occurrence of the total clade in the Old World, but cannot constrain the divergence timing of crown Colubroidea or the (Colubridae+Elapoidea) total clade.

\section{(6) Naja}

Node calibrated. Divergence between Naja and Haemachatus.

Fossil Taxon. Naja romani (Hoffstetter, 1939).

Specimen. UCBL 92856 partial skeleton including maxillae, prefrontal, postorbital, fragmentary parietal, parabasisphenoid, otoocipital, supratemporals, quadrates, articular, splenial, and dentary (Hoffstetter, 1939).

Additional Materials. Supraoccipital (BSP 1976 XXII 7668) (Szyndlar and Schleich, 1993), parabasisphenoid (No. 1984/98), partial pterygoids (No. 1984/104/1, 1984/ $104 / 2)$, right dentary $(1984 / 104 / 3)$, right frontal (1984/104/4), left maxilla (1984/99). See Szyndlar and Schleich (1993) and Bachmeyer and Szyndlar (1985) for additional cranial and vertebral elements.

Phylogenetic Justification. Assignment of to the genus Naja is based on an anteroposteriorly short and laterally recurved maxilla with two large anterior venom fangs and two solid posterior teeth (Hoffstetter, 1939; Bogert, 1943) and fenestra vestibuli completely or nearly completely bounded within the otooccipital (Hoffstetter, 1939; Szyndlar and Rage, 1990).

Minimum Age. 17.0 Ma

Soft Maximum Age. Indeterminate.

Age Justification. The minimum age is based on the maximum age for MN4, the age of the Petersbuch 2 locality (Szyndlar and Schleich, 1993; Ivanov, 2000; Agustí et al., 2001).

Discussion. Hoffstetter (1939) erected the taxon Paleonaja romani based on UCBL 92856. He considered the taxon to be most closely related to Ophiophagus hannah among extant cobras, with similarities to extant Naja the result of parallel evolution: "Toutes ces observations et les caractères morphologiques de detail mentionnés plus haut conduisent à admettre que P. romani est plus proche de $\mathrm{N}$. hannah que de toute autre espèce actuelle. Cependant, la dysharmonie de ses caractères ostéologiques rend improbable une filiation directe de la forme Miocène au type actuel. II semble plutôt que Palaeonaja romani représente un rameau parallèle à celui des Naja, et il convient de le 
designer sous un nom générique nouveau." (Hoffstetter, 1939:65). Bogert (1943) recommended assigning $P$. romani to the genus Naja, on the basis of anatomical similarities with extant $N$. haje, but did not provide specific character evidence. Szyndlar and Rage (1990) Paleonaja with Naja, and assigned N. romani to the Asiatic clade of Naja on the basis of a short vidian canal with an anterior opening bounded by the parabasisphenoid and the fenestra vestibule bounded by the otoocipital. Szyndlar and Zerova (1990) additionally proposed an Asian Naja affinity for $N$. romani on the basis of a narrow parabasisphenoid rostrum. Conversely, Wallach et al. (2014) assigned $N$. romani to the genus Afronaja as part of the African clade of cobras, without justification.

Based on cranial osteology, Naja romani can be used to unambiguously calibrate the divergence of Naja from Haemachatus (Pyron et al., 2013a). Calibrating divergences within Naja, however, is problematic. Of the characters used to unite $N$. romani with Asian Naja (Naja subgenus of Wallach et al., 2009), none are unambiguous synapomorphies of that clade: Enclosure of the fenestra vestibule within the otoocipital occurs in Naja naja but only polymorphically in other Asian species as well as African N. haje (Szyndlar and Rage, 1990); the anterior opening of the vidian canal within the parabasisphenoid additionally occurs in Pseudohaje and Aspidelaps (Szyndlar, 1992); short vidian canals occur in Pseudohaje, Aspidelaps, and N. haje (Szyndlar, 1992); and a comparably narrow parabasisphenoid occurs in Aspidelaps, and N. haje (Szyndlar, 1992). Additionally, N. romani possess the same maxillary tooth formula of two venom fangs and two solid posterior teeth as African Naja.

Other Neogene Naja species have been described on the basis of neurocranial anatomy. Naja antiqua, represented by a partial neurocranium and precloacal vertebrae from the middle Miocene (MN 7) of Morocco (Rage, 1976) and Naja iberica, represented by a partial neurocranium and skull roof from the latest Miocene (MN 13) of Spain (Szyndlar, 1985). Both taxa have been referred to the "African complex" of
Szyndlar and Rage (1990) on the basis of neurocranial characters. However, these characters are either explicitly recognized as plesiomorphic for the genus (Szyndlar and Rage, 1990, Szyndlar, 1992), or are untested with respect to phylogenetic polarity. Because elapine osteology has not been either rigorously optimized on a molecular phylogenetic topology or been used to construct a phylogenetic hypothesis, there is no way to unambiguously place the fossil record within the phylogeny of living species, and we here use the record to only constrain the Naja total clade (Wallach et al., 2009).

Fossils attributed to Naja primarily on the basis of precloacal vertebral morphology have been documented throughout the Neogene of Europe and Africa (Bachmeyer and Szyndlar, 1985, 1987; Szyndlar, 1985, 1991, 2009a,b; Meylan, 1987; Szyndlar and Zerova, 1987; Bailon, 1989; Szyndlar and Rage, 1990; Ivanov, 2000; Miklas-Tempfer, 2002; Rage, 2003; Daxner-Höck et al., 2004; Camora et al., 2010; Rage and Bailon, 2011; Blain et al., 2013); however, vertebral morphology is not diagnostic for the genus with respect to other elapid taxa (e.g., Smith, 1975; McCartney et al., 2014). The oldest record of the genus based on cranial elements is Naja romani from the early Miocene Petersbuch 2 locality of Germany (Szyndlar and Schleich, 1993). This record consists of a supraoccipital, frontal, dentary fragment, and partial compound bone. The supraoccipital is the only element explicitly discussed and is described as being morphology indifferent from supraoccipitals of extant Naja species (Szyndlar and Schleich, 1993).

\section{(7) Oxyuraninae}

Node Calibrated. Divergence between Laticauda+Oxyuraninae.

Fossil Taxon. Incongruelaps iteratus Scanlon et al. (2003).

Specimen. QM F23085, right maxilla.

Additional Materials. Six precloacal vertebrae.

Phylogenetic Justification. Assignment to Oxyuraninae is based on the presence of five posterior maxillary teeth and absence of a distinct palatine articular 
facet on the palatine process of the maxilla (Scanlon et al., 2003).

Minimum Age. 10 Ma (Myers et al., 2001; Scanlon et al., 2003).

Maximum Age. Indeterminate.

Age Justification. The minimum age is based on a combination of mammalian biostratigraphy and phylogenetic relationships of mammals from the Encore Local Fauna relative to the late Miocene Alcoota Local Fauna and the middle Miocene System C Local Fauna from Riversleigh (Myers et al., 2001).

Discussion. Scanlon et al. (2003) cited multiple qualitative characters of the maxilla that unite Incongruelaps with oxyuranines (sensu Sanders and Lee, 2008) and other elapids, and the aforementioned characters unite the taxon with Oxyuraninae to the exclusion of Laticauda. The Australian fossil record of Elapids extends from the Quaternary through the Neogene (e.g., Smith, 1976; Scanlon, 2003). The oldest record was previously considered to be latest Paleogene based on a precloacal vertebra from the RSO site of Riversleigh (Scanlon et al., 2003); however, RSO has been radiometrically dated to $16.55 \pm 0.29$ Ma (Woodhead et al., 2016). A maximum age for the divergence of the total clade Hydrophiinae is potentially determined from the first occurrences of Elapidae (e.g., McCartney et al., 2014 vs. Kuch et al., 2006), but we refrain from such a calibration due to the coarse phylogenetic resolution of those records.

\section{(8) Bungarus}

Node Calibrated. Divergence between Bungaurs bungaroides, B. flaviceps, and the $B$. fasciatus clade.

Fossil Taxon. Bungarus sp. Head (2005). Specimen. H-GSP 53026, partial precloacal vertebra.

Additional Materials. Six precloacal vertebrae.

Phylogenetic Justification. Assignment to the clade consisting of Bungarus species more closely related to each other than to $B$. bungaroides or $B$. flaviceps is based on the presence of both expanded prezygapophyseal accessory processes and postzygapophyseal accessory processes (McDowell, 1970; Slowinski, 1994).
Minimum Age. 10.215 Ma (Barry et al., 2002).

Maximum Age. Indeterminate.

Age Justification. The minimum age is based on the maximum age estimate for locality Y-450, the oldest record of Bungarus from the Siwalik Group of the Potwar Plateau, Pakistan (Barry et al., 2002; Head, 2005). Precise magnetostratigraphic analysis combined with sedimentation rate estimates has resolved Siwalik Group fossil localities to a temporal resolution of $10^{4}$ years (e.g., Flynn et al., 1990; Barry et al., 2002).

Discussion. Bungarus is one of the few snake taxa that can be diagnosed to subgeneric levels on the basis of vertebral synapomorphies (Hoffstetter, 1939; Slowinski, 1994). The hypertrophied, wing-like prezygapophyseal accessory processes are diagnostic for the genus, and the possession of the wing-like lateral postzygapophyseal processes diagnoses Bungarus species as more derived than $B$. flaviceps and $B$. bungaroides (McDowell, 1970; Slowinski, 1994). Presence of the posterior processes unites the Siwalik Group Bungarus with the unresolved polytomy of derived species from Slowinski (1994) or the clade subtended by $B$. faciatus and $B$. multicinctus from Pyron et al. (2013b).

\section{(9) Heterodon + Farancia}

Node Calibrated. Divergence between the clade subtended by Heterodon and Farancia.

Fossil Taxon. Paleheterodon tiheni (see discussion).

Specimen. UNSM 46504, partial skull and associated vertebrae.

Additional Materials. None (see discussion).

Phylogenetic Justification. Assignment of UNSM 46504 to a clade including Heterodon to the exclusion of Diadophis and Pseudoboa is based on the character combination of: 1) a quadrate with a narrow and strongly recurved distal shaft and a wide, narrow suprastapedial crest; 2) a narrow ventrally curved compound bone; 3) A parietal with a broad, well-defined skull table; 4) a supraoccipital with a welldefined sagittal crest.

Minimum Age. $\sim 12.08 \mathrm{Ma}$. 
Maximum Age. Indeterminate.

Age Justification. The minimum age is based on the Swallow Ash of the lowermost Ash Hollow Formation, which succeeds the Valentine Formation (Tedford et al., 2005). The Myers Farm fauna is coeval with the Valentine Formation based on mammalian faunal composition and is considered latest Barstovian (e.g., Janis et al., 1998; Bair, 2011).

Discussion. Paleoheterodon tiheni was originally described on the basis of three precloacal vertebrae from the Barstovian Nordern Bridge Quarry of Nebraska (Holman, 1964). Holman (1964:633) stated "The vertebrae of Paleoheterodon are undoubtedly closer to Heterodon than to any other North American genus" but did provide any character evidence in support and did not make any taxonomic comparisons in the description of the holotype. Holman (2000) noted that vertebral morphology of extant Heterodon differs from closely related dipsadine Farancia only in possessing a more depressed neural arch and a less anterorposteriorly undercut neural spine; however, there is no appreciable difference the amount of undercutting between the two taxa as illustrated by Holman (2000). Both Heterodon and Farancia do possess comparatively flattened and depressed neural arches. Whether this character is useful for recognizing Dipsadinae or constituent subclades will require additional taxonomic sampling. Holman (1977) described a partial skull and associated vertebrae from the late Barstovian Myers Farm locality of southern Nebraska as Paleoheterodon tiheni, uniting the taxon with Heterodon based on vertebral similarities but noting very different cranial morphologies. Holman (2000) noted that vertebral morphology of Paleoheterodon differed from Heterodon in having a less depressed neural arch, which, as previously noted, is the condition in Farancia.

Cranial elements referred to Paleoheterodon tiheni do show several similarities to extant Heterodon, contra Holman (1977, 2000). The distal quadrate is narrow and recurved in both taxa and the suprastapedial crest is similarly well-developed, and the compound bone is similarly narrow and recurved. Conversely, the basicranium and skull roof are radically different between the two taxa. Heterodon possesses an apomorphically short posterior skull, whereas cranial elements of Paleoheterodon include a comparatively elongate parietal and supratemporal with welldeveloped muscle attachment crests. The parabasiphenoid of Heterodon is abbreviated posterior to the sella turcica, whereas the same region is elongate in Paleoheterodon.

Morphology of vertebrae and cranial elements referred to Paleoheterodon is consistent with both Heterodon and Farancia (e.g., Cundall and Rossman, 1984). There are four possibilities for the identity of the taxon: 1) it is sister-taxon to Heterodon; 2) it is sister taxon to Farancia; 3 ) it is sister taxon to Heterodon+Farancia; and 4) UNSM 46504 is a chimera of multiple taxa. The possibility that cranial elements referred to Paleoheterodon tiheni represent multiple taxa is supported by the taphonomy of the Myers Farm site. Contra Holman (1977) there is almost no articulation or association of microvertebrate remains from the locality. Among squamates, only two partial snake precloacal skeletons were preserved in articulation and direct association. P. tiheni cranial specimens show damage consistent with transport, and the possibility that association of elements is a postmortem assemblage of multiple individual animals. Additionally, isolated snake cranial elements of similar sizes to $P$. tiheni cranial specimens have been recovered from the locality (JJH pers. obs.), and the absence of articulation between any of the elements described by Holman $(1977,2000)$ limits the ability to unambiguous assign the remains to a single individual or taxon. Because of this, we restrict the elements assigned to UNSM 46504 to only calibrate the most exclusive clade including Farancia and Heterodon to the exclusion of (Nothopsis+Pseudoboa).

The oldest unambiguous record of Heterodon is $H$. plionasicus from the middle Pliocene Fox Canyon Fauna of Kansas is represented by a maxilla that is anatomical identical to $H$. nasicus (Peters, 1953; Holman, 2000). 


\section{(10) Pantherophis+Pituophis.}

Node Calibrated. Divergence between the extant genera Pantherophis and Pituophis. Fossil Taxon. Pantherophis.

Specimen. UNSM 125457, complete, articulated skull and anterior $\sim 30$ of precloacal vertebral column.

Additional Materials. None.

Phylogenetic Justification. Assignment to Pantherophis is based on a premaxilla with thin, dorsomedially angled maxillary processes, a blunt, rounded anterior margin, and laterally expanded ascending processes forming a keyhole shape in anterior view.

Minimum Age. 11.93 Ma (Tucker et al., 2014).

Maximum Age. Indeterminate.

Age Justification. USNM 125457 was encased in a local ash deposit that is geochemically matched with the lbex Hollow Tuff, radiometrically dated to $11.93 \mathrm{Ma}$ (Tucker et al., 2014).

Discussion. USNM 125457 is a complete, slightly crushed and disarticulated skull of a colubrine snake. It possesses homodont maxillary dentition, a sharp, distinct lateral crest of the quadrate, and pterygoid dentition terminating well anterior to the quadrate ramus. Articulations of skull roofing elements, margins of the nasals, and morphology of the parabasisphenoid are identical to extant Pantherophis, and the lateral expansion of the premaxillary ascending process is uniquely shared between USNM 125457 and extant Pantherophis species.

Holman (1982) described a well-preserved skeleton from the latest Miocene Santee Local Fauna as Elaphe vulpina, and provided a definition of the species on the basis maxillary and dentary tooth counts, ectopterygoid shape, and quadrate morphology; however, none of these characters is apomorphic with respect to other Pantherophis species (e.g. P. obsoleta). Elaphe buisi from the early Pliocene of Oklahoma was described on the basis of cranial remains (Holman, 1973), but the interrelationships of the taxon to Bogertophis relative to Pantherophis are undetermined (Holman, 2000), and the taxon is currently uninformative with respect to divergence timings.
UNSM 125457 calibrates the Pantherophis+Pituophis divergence, regardless of the identities of younger Pantherophis/ Elaphe records. The oldest reports of Pituophis are based on four precloacal vertebrae from the late Miocene (Hemphillian) of Nebraska (Parmley and Holman, 1995:84). Assignment to Pituophis was based on ambiguous vertebral morphology (e.g., "neural spines high; neural arches vaulted"...) and a differential comparison with Pantherophis obsoleta. This identification additionally appears to include the distribution of extant Pituophis, which potentially introduces circularity in identifications and analysis of faunal histories (see Bell et al., 2010).

\section{DISCUSSION}

\section{Other Possible Fossil Calibrations}

The Neogene and Quaternary fossil record of colubrids includes several taxa described by cranial remains that have the potential to calibrate divergence timings of extant taxa, but are problematic with respect to systematics or anatomical interpretations. Malpolon mynarskii was described on the basis of a partial braincase from the late Pliocene of Spain and was assigned to the genus on the basis of: "considerable posterior expansion of the parietal, a very acute angle between the parietal crests throughout the bone, relatively very short basisphenoid portion of basiparasphenoid, ventral expansion of the middle of the basisphenoid, elongation of the vertebrae, a thin and sharp haemal keel, and straight posterior margins of the neural arch" (Szyndlar, 1988:693). However, Szyndlar (1988) noted other anatomical similarities with Elaphe s.l. and Coluber s.I. Natrix longivertebrata has been described on the basis of vertebrae and cranial elements from the middle Miocene through Pliocene of western and central Europe (Szyndlar, 1984; Rage and Szyndlar, 1986; Szyndlar, 2012). Referral of $N$. longivertebrata to Natricinae is based on vertebral morphology (Szyndlar, 1984), and no unambiguous apomorphies nesting the taxon within extant natricine taxa have been provided.

Hierophis viridiflavus has been described as Coluber robertmertensi and Coluber viridiflavus from multiple late Pliocene and Pleistocene European localities (e.g., Mlynarski, 1964; Szyndlar, 1984; Ivanov, 1995; Szyndlar, 2012). A single character, a strongly posteriorly inclined anterior border 
of the vomerine process of the palatine, has been used to refer a specimen to $H$. viridiflavus (Szyndlar, 1984); however, most of the described record for the species consists of vertebrae or other cranial elements. As a result, we do not formally include the taxon as a calibration point, but recognize its potential utility following reassessment and phylogenetic analysis.

Two fossil genera based partially on cranial remains have the potential for constraining inclusive colubroid clades. Proptychophis achoris from the late Miocene of California includes a right maxilla possessing a unique combination of dental characters (Whistler and Wright, 1989), and Dryinoides oxyrhachis from the middle Miocene of Montana includes a partial skull roof and suspensorium (Auffenberg et al., 1958). Determination of the phylogenetic relationships of these taxa will very likely be important for understanding the evolution of modern North American colubrids.

The published fossil record of coral snakes consists of specimens from the Neogene and Quaternary of North America and Europe. All have been assigned to Micrurus (Holman, 1977; Rage and Holman, 1984; Holman, 2000; Ivanov, 2000; Szyndlar, 2009; Ivanov and Böhme, 2011; Venczel, 2011). Holman (1977) and Rage and Holman (1984) distinguish Micrurus gallicus from the Astaracien of France and Micrurus sp. indet. from the Barstovian of Nebraska from Micruroides on the basis of relatively taller neural spines in extant Micrurus and fossil specimens. Vertebral morphology cannot distinguish Micrurus from Sinomicrurus (Holman, 1977; Dowling and Duellman, 1978; Roze, 1996; Ikeda, 2007), and the records of $M$. gallicus and North American indeterminate species records cannot be unambiguously assigned to genus.

Vertebral anatomy of "Elapidae gen. et sp. indet." (Ivanov, 2002) from the Merkur-North locality (early Miocene, MN3) of the Czech Republic is anatomically most similar to Micruroides and Leptomicrurus in possessing an extremely short neural spine (Holman, 1977; Roze, 1996); however, vertebral morphologies for Maticora and Calliophis, which are either considered the sister taxon to Sinomicrurus+(Micrurus + Micruroides) in the case of Maticora, or resolved as the sister taxon to all other elapids in the case of Calliophis (Pyron et al., 2013a, b), are undocumented. If morphologies for these taxa are indistinguishable from Sinomicrurus, Micrurus, and Micruroides, then the fossil records described here may only minimally constrain the divergence of crown Elapidae (Figure 1).
Due to the lack of information on vertebral morphology in extant coral snakes, it is currently not possible to calibrate divergence timings with this undoubtedly important fossil record.

\section{Comparisons with Previous Fossil Calibrations for Caenophidians}

Fossil calibrations have been applied to molecular phylogenetic analyses of most caenophidian clades, with little consensus on particular fossils. Noonan and Chippindale (2006) used the fossil record of nigerophiid snakes to calibrate a Paleogene divergence for Acrochordus. This calibration is highly problematic because the fossil record of nigerophiids extends into the Cretaceous and because there is no evidence to support monophlyly of Acrochordus and Nigerophiidae (see Sanders et al., 2010 for additional discussion). Sanders et al. (2010) calibrated divergence timings for Acrochordus species as well as singleton representatives of Colubridae and Elapidae and two viperids based on the Acrochordus fossil record described here and the early Miocene viperid and elapid records of Kuch et al. (2006). Lukoschek et al. (2012) iteratively used different calibrations ranging from 34-80 Ma to calibrate the divergence of Acrochordus based on correct ages of nigerophiids and early records of colubroids.

Wüster et al. (2008) employed similar records to those described here to minimally calibrate the divergence of Eurasian viperines, but used a reported record of late Miocene Sistrurus (Parmley and Holman, 2007) that we do not recognize due to absence of character support for assignment beyond Viperidae. Wüster et al. $(2007,2008)$, and Kelly et al. (2009) followed the interpretation of Naja romani as a member of the Asian Naja clade (Szyndlar and Rage, 1990) to calibrate the divergence of Asian and African species. Conversely this analysis restricts calibrations of $N$. romani to only the Naja total clade (see also Lukoschek et al., 2012).

Fossil calibrations for Hydrophiinae have primarily employed an early Miocene record referred to Laticauda by Scanlon et al. (2003) (Wüster et al., 2007). Both the age and identity of the record have been revised (see Sanders and Lee, 2008 for discussion), and our recommended use of Incongruelaps as the minimum calibration for Laticauda and Oxyuraninae is temporally consistent with the divergence estimated by Sanders and Lee (2008) using other dates.

Calibrations for Colubroidea and Colubridae are highly divergent (e.g., Wüster et al., 2007; 


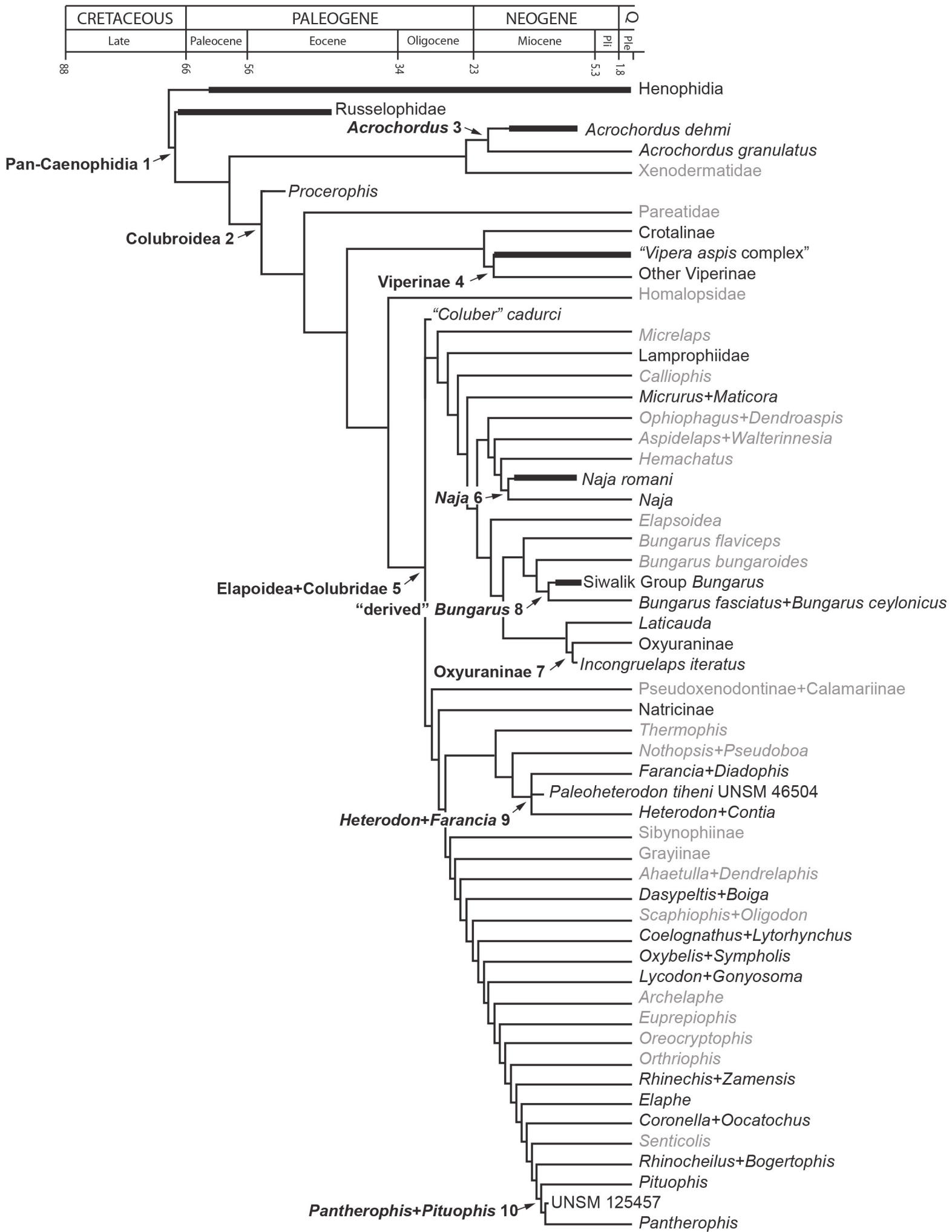

FIGURE 1. Phylogeny of Caenophidia from Pyron et al. (2013a) temporally calibrated on minimum ages reported here. Taxon names in grey have not been described in the fossil record. Taxon names in black have been described from fossils. See Holman (2000) and Szyndlar (2012) for records. Taxa labeled with two identifiers represent the most inclusive clades subtended by those identifiers following Pyron et al. (2013a). 
Alfaro et al. 2008; Lukoschek et al., 2012), and rely on reports of colubroids as early as Cenomanian (Rage and Werner, 1999, but see Head et al., 2005; Head, 2015; this study) to the first occurrence of Coluber cadurci (Lukoschek et al., 2012). Pyron and Burbrink (2012) employ the same calibration as advocated here for Colubroidea, the Paleogene taxon Procerophis. They calibrate the stem-group age of Colubridae using the Oligocene taxon Texasophis. The identity of Texasophis as a member of the Colubridae+Elapoidea crown has not been determined by unambiguous apomorphies, however, and we recommend the slightly younger Coluber cadurci as the calibration of that clade.

\section{Biogeographic Histories Inferred from the Fossil Record}

A direct reading of the of Caenophidia fossil record indicates a latest Late Cretaceous origin likely in Gondwanan landmasses based on African and South American russellophiids (Rage and Werner, 1999; Rage, 2008) with the oldest colubroids occurring in continental sediments of the Cambray Formation of northern India by the early Eocene (Rage et al., 2008). Whether or not the Cambray colubroid record represents a Gondwanan fauna subsequently docked with Asia or an Asian fauna dispersing into India is indeterminate due to the Laurasian composition of the local mammal faunas (Rana et al., 2008; Rose et al., 2008) and early Paleogene records of European russellophiids (Rage, 1976). Unambiguous pan-colubroids disperse across Europe and Asia and into North America and Africa by the late Eocene (Rage et al., 1992; Parmley and Holman, 2003; Head et al., 2005; McCartney and Seiffert, 2015). Colubroids anatomically consistent with the crown clade of Colubridae+Elapoidea appear in North America and Europe during the early to middle Oligocene (Holman, 1999; Szyndlar, 2012), and appear in Sub-Saharan Africa by the late Oligocene (McCartney et al., 2014).

Dispersal of caenophidians into South America from North America and Australia from Asia occurred during the Neogene. Colubroid fossils are present in South America from the middle Miocene on (Hoffstetter and Rage, 1977; Albino, 1996; Albino and Montalvo, 2006; Head et al., 2006; Albino and Brizuela, 2014), consistent with an early to middle Miocene immigration conduit between Central and South America, as evidenced by other snake taxa (Head et al., 2012). The first occurrence of colubroids in Australia is late early Mio- cene and consists of elapoid remains (Scanlon et al., 2003 after Woodhead et al., 2016).

Among colubroid subclades, the temporal and geographic origins of Elapoidea and Viperidae are most poorly understood. The high diversity of Elapoidea, as well as endemicity of many subclades, in Africa is suggestive of an African origin for the clade, and the oldest fossils referred to Elapidae are from the late Oligocene of Africa (McCartney et al., 2014). However, an African origin requires either an early Paleogene immigration into Africa with subsequent isolation or a Gondwanan origin of the clade, which would require an Early Cretaceous divergence from Colubridae. This section scenario is highly unlikely given everything that is known about the fossil record of caenophidians, the fossil records of "henophidian" sister taxa, and rates of molecular evolution.

The origin and earliest evolution of Viperidae is unknown in the fossil record. Viperids first appear in the early Miocene of Europe and then the late early Miocene of North America, Asia, and Africa (Szyndlar and Rage, 1999). Immigration into South America occurred by the middle Miocene (Albino and Montalvo, 2006). Despite the distinctive morphology of both cranial and axial osteology in viperids, there is no fossil evidence of the clade in the Paleogene. The sister-taxon relationships with Colubridae+Elapoidea requires at least a midPaleogene divergence of the viperid lineage, and the absence of identifiable viperids from approximately-aged sediments in Europe, North America, and North Africa suggests that the evolution of the viperid crown clade and its diagnostic skeletal morphology may have been a comparatively recent event relative to colubrids and elapoids.

For caenophidians, as well as other squamates, the last occurrence of archaic taxa and the first occurrence of specimens referable to extant taxa is during the Miocene for the majority of documented clades. Whether the timing of modernization in squamate faunas results from climatic changes from the Paleogene world, biotic changes in ecosystem trophic structures (Rabb and Marx, 1973; Parmley and Holman, 1995), or the evolution of highly toxic venoms (e.g, Savitzky, 1980), remains to be determined, but will require combining fossil, sedimentological, and molecular data in a comprehensive study.

\section{ACKNOWLEDGEMENTS}

For discussion and encouragement, we thank J. Parham and D. Ksepka. We thank C. Bell for access to obscure literature. This research was 
funded by by the Deutsche Forschungsgemeinschaft (MU 1760/4-1; to JM and JJH). JJH was additionally funded by National Science Foundation grant EAR-1338028.

\section{REFERENCES}

Agustí, J., Cabrera, L., Garcés, M., Krijgsman, W., Oms, O. and Parés, J.M. 2001. A calibrated mammal scale for the Neogene of Western Europe. State of the art. Earth-Science Reviews, 52:247-260.

Albino, A.M. 1996. Snakes from the Miocene of Patagonia (Argentina) Part II: The Colubroidea. Neues Jahrbuch fur Geologie und Palaontologie-Abhandlungen, 200:353-360.

Albino, A.M. and Brizuela, S. 2014. An overview of the South American fossil squamates. The Anatomical Record, 297:349-368.

Albino, A.M. and Montalvo, C.I. 2006. Snakes from the Cerro Azul Formation (Upper Miocene), central Argentina, with a review of fossil viperids from South America. Journal of Vertebrate Paleontology, 26:581587.

Alfaro, M.E., Karns, D.R., Voris, H.K., Brock, C.D., and Stuart, B.L. 2008. Phylogeny, evolutionary history, and biogeography of Oriental-Australian rear-fanged water snakes (Colubroidea: Homalopsidae) inferred from mitochondrial and nuclear DNA sequences. Molecular Phylogenetics and Evolution, 46:576-593.

Auffenberg, W., Mook, C.C., and Williams, C.S. 1958. A new genus of colubrid snake from the Upper Miocene of North America. American Museum Novitates, 1874:1-16.

Bachmayer, F. and Szyndlar, Z., 1985. Ophidians (Reptilia: Serpentes) from the Kohfidisch fissures of Burgenland, Austria. Annalen des Naturhistorischen Museums in Wien, 87:79-100.

Bachmayer, F. and Szyndlar, Z. 1987. A second contribution to the ophidian fauna (Reptilia: Serpentes) of Kohfidisch, Austria. Annalen des Naturhistorischen Museums in Wien, 88:25-39.

Bailon, S. 1989. Les amphibiens et les reptiles du Pliocène supérieur de Balaruc II (Hérault, France). Palaeovertebrata, 19:7-28.

Bair, A.R. 2011. Description of a new species of the North American archaic pika Hesperolagomys (Lagomorpha: Ochotonidae) from the middle Miocene (Barstovian) of Nebraska and reassessment of the genus Hesperolagomys. Palaeontologia Electronica, Vol. 14:6A:49p;?http://palaeo-electronica.org/2011_1/ 202/index.html

Bajpai, S., Kapur, V.V., Das, D.P., Tiwari, B.N., Saravanan, N., and Sharma, R., 2005. Early Eocene land mammals from the Vastan Lignite Mine, District Surat (Gujarat), western India. Journal of the Palaeontological Society of India, 50:101-113.
Barry, J.C., Morgan, M.E., Flynn, L.J., Pilbeam, D., Behrensmeyer, A.K., Raza, S.M., Khan, I.A., Badgley, C., Hicks, J., and Kelley, J. 2002. Faunal and environmental change in the Late Miocene Siwaliks of Northern Pakistan. Paleobiology, 28(suppl. To 2):1-71.

Bell, C.J., Gauthier, J.A., and Bever, G.S. 2010. Covert biases, circularity, and apomorphies: A critical look at the North American Quaternary herpetofaunal stability hypothesis. Quaternary International, 217:30-36.

Bell, C.J., Head, J.J., and Mead, J.I. 2004. Synopsis of the herpetofauna from Porcupine Cave, p. 117-126. In Barnosky, A.D. (ed.), Biodiversity Response to Climate Change in the Middle Pleistocene. The Porcupine Cave Fauna from Colorado. Berkeley: University of California Press.

Bellairs, A.A. and Underwood, G. 1951. The origin of snakes. Biological Reviews, 26:193-237.

Blain, H.A., Agustí, J., López-García, J.M., Haddoumi, H., Aouraghe, H., Hammouti, K.E., Pérez-González, A., Chacón, M.G., and Sala, R. 2013. Amphibians and squamate reptiles from the late Miocene (Vallesian) of eastern Morocco (Guefaït-1, Jerada Province). Journal of Vertebrate Paleontology, 33:804-816.

Bogert, C.M. 1943. Dentitional phenomena in cobras and other elapids, with notes on adaptive modifications of fangs. Bulletin of the American Museum of Natural History, 81:285-360.

Burbrink, F.T. 2002. Phylogeographic analysis of the cornsnake (Elaphe guttata) complex as inferred from maximum likelihood and Bayesian analyses. Molecular Phylogenetics and Evolution, 25:465-476.

Burbrink, F.T., Fontanella, F., Pyron, R.A., Guiher, T.J., and Jimenez, C. 2008. Phylogeography across a continent: the evolutionary and demographic history of the North American racer (Serpentes: Colubridae: Coluber constrictor). Molecular Phylogenetics and Evolution, 47:274-288.

Burbrink, F.T. and Lawson, R. 2007. How and when did Old World ratsnakes disperse into the New World? Molecular Phylogenetics and Evolution, 43:173-189.

Burbrink, F.T., Lawson, R., and Slowinski, J.B. 2000. Mitochondrial DNA phylogeography of the polytypic North American rat snake (Elaphe obsoleta): a critique of the subspecies concept. Evolution, 54:21072118.

Burbrink, F.T. and Pyron, R.A. 2010. How does ecological opportunity influence rates of speciation, extinction, and morphological diversification in New World ratsnakes (tribe Lampropeltini)?. Evolution, 64:934943.

Carmona, R., Alba, D.M., Delfino, M., Robles, J.M., Rotgers, C., Mengual, J.V.B., Balaguer, J., Galindo, J., and Moyà-Solà, S. 2010. Snake fossil remains from the Middle Miocene stratigraphic series of Abocador de Can Mata (els Hostalets de Pierola, Catalonia, Spain). Cidaris, 30:77-83. 
Cernansky, A., Rage, J.-C., and Klembara, J. 2014. The early Miocene squamates of Amöneburg (Germany): the first stages of modern squamates in Europe. Journal of Systematic Palaeontology, http:// dx.doi.org/10.1080/14772019.2014.897266

Cundall, D. and Rossman, D.A. 1984. Quantitative comparisons of skull form in the colubrid snake genera Farancia and Pseudoeryx. Herpetologica, 40:388405.

Daxner-Höck, G., Milas-Tempfer, P.M., Gölich, U.B., Huttunen, K., Kazàr, E., Nagel, D., Roessner, G.E., Schultz, O., and Ziegler, R. 2004. Marine and terrestrial vertebrates from the middle Miocene of Grund (lower Austria). Geologica Carpathica, 55:1-7.

Dowling, H.G., and Duellman, W.E. 1978. Systematic herpetology: a synopsis offamilies and higher categories. HISS Publications, New York.

Flynn, L.J., Pilbeam, D., Jacobs, L.L., Barry, J.C., Behrensmeyer, A.K., and Kappelman, J.W. 1990. The Siwaliks of Pakistan: time and faunas in a Miocene terrestrial setting. The Journal of Geology, 98:589604.

Fry, B.G., Scheib, H., van der Weerd, L., Young, B., McNaughtan, J., Ramjan, S. F.R., Vidal, N., Poelmann, R.E., and Norman, J.A. 2008. Evolution of an arsenal structural and functional diversification of the venom system in the advanced snakes (Caenophidia). Molecular \& Cellular Proteomics, 7:215-246.

Fry, B.G., Wüster, W., Kini, R.M., Brusic, V., Khan, A., Venkataraman, D., and Rooney, A.P. 2003. Molecular evolution and phylogeny of elapid snake venom three-finger toxins. Journal of Molecular Evolution, 57:110-129.

Göhlich, U.B. and Mourer-Chauviré, C. 2005. Revision of the phasianids (Aves: Galliformes) from the lower Miocene of Saint-Gérand-le-Puy (Allier, France). Palaeontology, 48:1331-1350.

Gómez, R.O., Báez, A.M., and Rougier, G.W. 2008. An anilioid snake from the Upper Cretaceous of northern Patagonia. Cretaceous Research, 29:481-488.

Gravlund, P. 2001. Radiation within the advanced snakes (Caenophidia) with special emphasis on African opistoglyph colubrids, based on mitochondrial sequence data. Biological Journal of the Linnean Society, 72:99-114.

Head, J.J. 2002. Snake paleontology of the Siwalik Group (Miocene) of Pakistan: Correlation of a rich fossil record to environmental histories. Ph.D. dissertation, Southern Methodist University, Dallas, TX, USA.

Head, J.J. 2005. Snakes of the Siwalik Group (Miocene of Pakistan): systematics and relationship to environmental change. Palaeontologia Electronica, 8(1):16A.

Head, J.J. 2015. Fossil calibration dates for molecular phylogenetic analysis of snakes 1: Serpentes, Alethinophidia, Boidae, Pythonidae. Palaeontologia Electronica, 18:1-17.
Head, J.J. and Bell, C.J. 2008. Snakes from Lemudong'o, Kenya Rift Valley. Kirtlandia, 56:177-179.

Head, J.J., Holroyd, P.A., Hutchison, J.H., and Ciochon, R.L. 2005. First report of snakes (Serpentes) from the late middle Eocene Pondaung Formation, Myanmar. Journal of Vertebrate Paleontology, 25:246-250.

Head, J.J., Mohabey, D.M., and Wilson, J A. 2007. Acrochordus Hornstedt (Serpentes, Caenophidia) from the Miocene of Gujarat, Western India: temporal constraints on dispersal of a derived snake. Journal of Vertebrate Paleontology, 27:720-723.

Head, J.J., Rincon, A., Suarez, C., Montes C., and Jaramillo, C. 2012. Evidence for American interchange during the earliest Neogene: Boa from the Miocene of Panama. Journal of Vertebrate Paleontology, 32:1328-1334.

Head, J.J., Sánchez-Villagra, M.R., and Aguilera, O. 2006. Fossil snakes from the Neogene of Venezuela (Falcón State). Journal of Systematic Palaeontology, 4:233-240.

Hedges, S.B., Couloux, A., and Vidal, N. 2009. Molecular phylogeny, classification, and biogeography of West Indian racer snakes of the Tribe Alsophiini (Squamata, Dipsadidae, Xenodontinae). Zootaxa, 2067:1-28.

Hilgen, F.J., Lourens, L.J., and Van Dam, J.A. 2012. The Neogene Period, p. 923-978. In Gradstein, F. Ogg, J.G., Schmitz, M., and Ogg, G (eds.), The Geologic Time Scale 2012. Elsevier, Amsterdam.

Hoffstetter, R. 1939. Contribution a l'étude des Elapidae actuels et fossiles et de l'ostéologie des ophidians. Archives du Muséum d'Histoire Naturelle de Lyon, 15:1-78.

Hoffstetter, R. 1964. Les serpents du Néogène du Pakistan (couches des Siwaliks). Bulletin de la Société Géologique de France, Série 7, 6:467-474.

Hoffstetter, R. and Gasc, J.-P. 1969. Vertebrae and ribs of modern reptiles, p. 201-310. In Gans, C. (ed.), Biology of the Reptilia, Volume 1: Morphology. Academic Press, London.

Hoffstetter, R. and Rage J.-C. 1977. Le gisement de vertébrés Miocènes de La Venta (Colombie) et sa faune de serpents. Annales de Paléontologie, 63:161-190.

Holman, J.A. 1973. A new Pliocene snake, genus Elaphe, from Oklahoma. Copeia, 1973:574-580.

Holman, J.A. 1977. Upper Miocene snakes (Reptilia, Serpentes) from Southeastern Nebraska. Journal of Herpetology, 11:323-335.

Holman, J.A., 1982. A fossil snake (Elaphe vulpina) from a Pliocene ash bed in Nebraska. Transactions of the Nebraska Academy of Science, 10:37-42.

Holman, J.A. 1999. Early Oligocene (Whitneyan) snakes from Florida (USA), the second oldest colubrid snakes in the North America. Acta Zoologica Cracoviensia, 42:447-454.

Holman, J.A. 2000. The fossil snakes of North America. Indiana University Press, Indianapolis. 
Ikeda, T. 2007. A comparative morphological study of the vertebrae of snakes occurring in Japan and adjacent regions. Current Herpetology, 26:13-34.

Ivanov, M. 1995. Pleistocene Reptiles at the Locality of the Stránská Skála Hill, p. 93-109. In Musil, R. (ed.), Stránská Skála Hill. Excavation of open-air sediments 1964-1972. Moravian Museum, Brno, Anthropos series, 26.

Ivanov, M. 1999. The first European pit viper from the Miocene of Ukraine. Acta Palaeontologica Polonica, 44:327-334.

Ivanov, M. 2000. Snakes of the lower/middle Miocene transition at Vieux Collonges (Rhône, France), with comments on the colonisation of western Europe by colubroids. Geodiversitas, 22:559-588.

Ivanov, M. 2002. The oldest known Miocene snake fauna from Central Europe: Merkur-North locality, Czech Republic. Acta Palaeontologica Polonica, 47:513534.

Ivanov, M. and Böhme, M. 2011. Snakes from Griesbeckerzell (Langhian, Early Badenian), North Alpine Foreland Basin (Germany), with comments on the evolution of snake faunas in Central Europe during the Miocene Climatic Optimum. Geodiversitas, 33:411-449.

Janis, C.M., Scott, K.M., and Jacobs, L.L. 1998. Evolution of Tertiary Mammals of North America: Terrestrial carnivores, ungulates, and ungulatelike mammals (Vol. 1). Cambridge University Press.

Kelly, C.M., Barker, N.P., and Villet, M.H. 2003. Phylogenetics of advanced snakes (Caenophidia) based on four mitochondrial genes. Systematic Biology, 52:439-459.

Kelly, C.M., Barker, N.P., Villet, M.H., and Broadley, D. G. 2009. Phylogeny, biogeography and classification of the snake superfamily Elapoidea: a rapid radiation in the late Eocene. Cladistics, 25:38-63.

Keogh, J.S. 1998. Molecular phylogeny of elapid snakes and a consideration of their biogeographic history. Biological Journal of the Linnean Society, 63:177203.

Keogh, S.J., Scott, I.A., Fitzgerald, M., and Shine, R. 2003. Molecular phylogeny of the Australian venomous snake genus Hoplocephalus (Serpentes, Elapidae) and conservation genetics of the threatened $H$. stephensii. Conservation Genetics, 4:57-65.

Kuch, U., Müller, J., Mödden, C., and Mebs, D. 2006. Snake fangs from the Lower Miocene of Germany: evolutionary stability of perfect weapons. Naturwissenschaften, 93:84-87.

LaDuke, T.C. 1991a. Morphometric variability of the precaudal vertebrae of Thamnophis sirtalis sirtalis (Serpentes: Colubridae), and implications for interpretation of the fossil record. Unpubl. Ph.D. diss., City Univ. of New York, New York.

LaDuke, T.C. 1991b. The fossil snakes of Pit 91, Rancho La Brea, California. Natural History Museum of Los Angeles County Contributions in Science, 424:1-28.
LaDuke, T.C., Krause, D.W., Scanlon, J.D., and Kley, N.J. 2010. A Late Cretaceous (Maastrichtian) snake assemblage from the Maevarano Formation, Mahajanga Basin, Madagascar. Journal of Vertebrate Paleontology, 30:109-138.

Lawson, R., Slowinski, J.B., Crother, B.I., and Burbrink, F.T. 2005. Phylogeny of the Colubroidea (Serpentes): new evidence from mitochondrial and nuclear genes. Molecular Phylogenetics and Evolution, 37:581-601.

Lukoschek, V. and Keogh, J.S. 2006. Molecular phylogeny of sea snakes reveals a rapidly diverged adaptive radiation. Biological Journal of the Linnean Society, 89:523-539.

Lukoschek, V., Keogh, J.S., and Avise, J.C. 2012. Evaluating fossil calibrations for dating phylogenies in light of rates of molecular evolution: a comparison of three approaches. Systematic Biology, 61:22-43.

McCartney, J.A. and Seiffert, E.R. 2015. A late Eocene snake fauna from the Fayum Depression, Egypt. Journal of Vertebrate Paleontology, p.e1029580.

McCartney, J.A., Stevens, N.J., and O'Connor. P.M. 2014. The Earliest Colubroid-Dominated Snake Fauna from Africa: Perspectives from the Late Oligocene Nsungwe Formation of Southwestern Tanzania. PLoS ONE 9(3): e90415. doi:10.1371/journal.pone.0090415

McDiarmid, R.W., Campbell, J.A., and Touré, T's.A. 1999. Snake Species of the World. A Taxonomic and Geographic Reference, Volume 1. The Herpetologists' League. Washington.

McDowell, S.B. 1970. On the status and relationships of the Solomon Island elapid snakes. Journal of Zoology, 161:145-190.

Meylan, P.A. 1987. Fossil snakes from Laetoli, p. 78-82. In Leakey, M.D. and Harris, J.M. (eds.), The Pliocene Site of Laetoli, northern Tanzania. Oxford University Press.

Miklas-Tempfer, P.M. 2002. The Miocene Herpetofaunas of Grund (Caudata; Chelonii, Sauria, Serpentes) and Mühlbach am Manhartsberg (Chelonii, Sauria, Amphisbaenia, Serpentes), Lower Austria. Annalen des Naturhistorischen Museums in Wien, 104:195235.

Młynarski, M. 1964. Die jungpliozäne Reptilienfauna von Rebielice Królewskie, Polen. Senckenbergiana Biologica, 45:325-347.

Mohabey, D.M., Head, J.J., and Wilson, J.A. 2011. A new species of the snake Madtsoia from the Upper Cretaceous of India and its paleobiogeographic implications. Journal of Vertebrate Paleontology, 31:588595.

Murphy, J.C., Mumpuni, and Sanders, K.L. 2011. First molecular evidence for the phylogenetic placement of the enigmatic snake genus Brachyorrhos (Serpentes: Caenophidia). Molecular Phylogenetics and Evolution, 61:953-957. 
Myers, T., Crosby, K., Archer, M., and Tyler, M. 2001. The Encore local Fauna, a late Miocene assemblage from Riversleigh, northwestern Queensland. Memoirs of the Association of Australasian Palaeontologists, 25:147-154.

Nagy, Z.T., Joger, U., Wink, M., Glaw, F., and Vences, M. 2003. Multiple colonization of Madagascar and Socotra by colubrid snakes: evidence from nuclear and mitochondrial gene phylogenies. Proceedings of the Royal Society of London B, 270:2613-2621.

Noonan, B.P. and Chippindale, P.T. 2006. Vicariant origin of Malagasy reptiles supports Late Cretaceous Antarctic land bridge. The American Naturalist, 168:730741.

Ogg, J.G., Hinnov, L.A., and Huang, C. 2012. Cretaceous, p. 793-854. In Gradstein, F. Ogg, J.G., Schmitz, M., and Ogg, G. (eds.), The Geologic Time Scale 2012. Elsevier, Amsterdam.

Parham, J.F., Donoghue, P.C.J., Bell, C.J., Calway, T.D., Head, J.J., Holroyd, P.A., Inoue, J.G., Irmis, R.B., Joyce, W.G., Ksepka, D.T., Patańe, J.S.L.N., Smith, D., Tarver, J.E., van Tuinen, M., Yang, Z., Angielczyk, K.D., Greenwood, J., Hipsley, C.A., Jacobs, L.L., Makovicky, P.J., Müller, J., Smith, K.T., Theodor, J.M., Warnock, R.C.M., and Benton, M.J. 2012. Best practices for applying paleontological data to molecular divergence dating analyses. Systematic Biology, 61:346-359.

Parmley, D. and Holman, J.A., 1995. Hemphillian (late Miocene) snakes from Nebraska, with comments on Arikareean through Blancan snakes of midcontinental North America. Journal of Vertebrate Paleontology, 15:79-95.

Parmley, D. and Holman, J.A. 2003. Nebraskophis Holman from the Late Eocene of Georgia (USA), the oldest known North American colubrid snake. Acta Zoologica Cracoviensia, 46:1-8.

Parmley, D. and Holman, J.A. 2007. Earliest fossil record of a pigmy rattlesnake (Viperidae: Sistrurus Garman). Journal of Herpetology, 41:141-144.

Peters, J.A. 1953. A fossil snake of the genus Heterodon from the Pliocene of Kansas. Journal of Paleontology, 27:328-331.

Pinou, T., Vicario, S., Marschner, M., and Caccone, A. 2004. Relict snakes of North America and their relationships within Caenophidia, using likelihood-based Bayesian methods on mitochondrial sequences. Molecular Phylogenetics and Evolution, 32:563-574.

Prasad, G.V.R. and Rage, J.-C. 1995. Amphibians and squamates from the Maastrichtian of Naskal, India. Cretaceous Research, 16:95-107.

Pritchard, A.C., McCartney, J.A., Krause, D.W., and Kley, N.J. 2014. New snakes from the Upper Cretaceous (Maastrichtian) Maevarano Formation, Mahajanga Basin, Madagascar. Journal of Vertebrate Paleontology, 34:1080-1093
Pyron, R.A. and Burbrink, F.T. 2009a. Neogene diversification and taxonomic stability in the snake tribe Lampropeltini (Serpentes: Colubridae). Molecular Phylogenetics and Evolution, 52:524-529.

Pyron, R.A. and Burbrink, F.T. 2009b. Can the tropical conservatism hypothesis explain temperate species richness patterns? An inverse latitudinal biodiversity gradient in the New World snake tribe Lampropeltini. Global Ecology and Biogeography, 18:406-415.

Pyron, R.A. and Burbrink, F.T. 2009c. Systematics of the Common Kingsnake (Lampropeltis getula; Serpentes: Colubridae) and the burden of heritage in taxonomy. Zootaxa, 2241:22-32.

Pyron, R.A. and Burbrink, F.T. 2012. Extinction, ecological opportunity, and the origins of global snake diversity. Evolution, 66:163-178.

Pyron, R.A., Burbrink, F.T., and Wiens, J.J. 2013a. A phylogeny and revised classification of Squamata, including 4161 species of lizards and snakes. BMC Evolutionary Biology, 13:93.

Pyron, R.A., Burbrink, F.T., Colli, G.R., De Oca, A.N.M., Vitt, L.J., Kuczynski, C. A., and Wiens, J.J. 2011. The phylogeny of advanced snakes (Colubroidea), with discovery of a new subfamily and comparison of support methods for likelihood trees. Molecular Phylogenetics and Evolution, 58:329-342.

Pyron, R.A., Kandambi, H.D., Hendry, C.R., Pushpamal, V., Burbrink, F.T., and Somaweera, R. 2013b. Genuslevel phylogeny of snakes reveals the origins of species richness in Sri Lanka. Molecular Phylogenetics and Evolution, 66:969-978.

Rabb, G.B. and Marx, H. 1973. Major ecological and geographic patterns in the evolution of colubroid snakes. Evolution, 27:69-83.

Rage, J.-C. 1973. Fossil snakes from Olduvai, Tanzania. Fossil vertebrates of Africa, 3:1-6.

Rage, J.-C. 1975. Un Caenophidien primitif (Reptilia, Serpentes) dans l'Eocene inferieur. Compte Rendu Sommaire des Séances de la Société Géologique de France, 2:46-47.

Rage, J.-C. 1976. Les squamates du Miocène de Béni Mellal, Maroc. Géologie Méditerranéene, 2:57-70.

Rage, J.-C. 1984. Encyclopedia of Paleoherpetology, part 11, Serpentes. Gustav Fischer Verlag, Stuttgart.

Rage, J.-C. 2003. Squamate reptiles from the early Miocene of Arrisdrift (Namibia) p. 43- 50. In Senut, B. and Pickford, M. (eds.), Geology and Palaeobiology of the central and southern Namib. Vol. 2: Palaeontology of the Orange River valley, Namibia. Memoir of the Geology Survey of Namibia (Ministry of Mines and Energy, Windhoeck), 19.

Rage, J.-C. 2008. Fossil snakes from the Paleocene of São José de Itaboraí, Brazil. Part III. Ungaliophiinae, boiids incertae sedis, and Caenophidia. Summary, update and discussion of the snake fauna from the locality Palaeovertebrata, 36:37-73.

Rage, J.C. and Augé, M. 1993. Squamates from the Cainozoic of the western part of Europe. A review. Revue de Paléobiologie, 7:99-216. 
Rage, J.-C. and Bailon, S. 2005. Amphibians and squamate reptiles from the late early Miocene (MN 4) of Béon 1 (Montréal-du-Gers, southwestern France). Geodiversitas, 27:413-441.

Rage, J.C. and Bailon, S. 2011. Amphibia and Squamata, p. 467-478. In Harrison, T. (ed.), Paleontology and geology of Laetoli: Human evolution in context. Volume 2. Springer Netherlands.

Rage, J.-C., Bajpai, S., Thewissen, J.G. and Tiwari, B.N. 2003. Early Eocene snakes from Kutch, Western India, with a review of the Palaeophiidae. Geodiversitas, 25:695-716.

Rage, J.-C., Buffetaut, E., Buffetaut-Tong, H., Chaimanee, Y., Ducrocq, S., Jaeger, J.J. and Suteethorn, V. 1992. A colubrid snake in the late Eocene of Thailand: the oldest known Colubridae (Reptilia, Serpentes). Comptes rendus de l'Académie des sciences. Série 2, Mécanique, Physique, Chimie, Sciences de l'univers, Sciences de la Terre, 314:1085-1089.

Rage, J.-C. and Danilov, I.G. 2008. A new Miocene fauna of snakes from eastern Siberia, Russia: Was the snake fauna largely homogenous in Eurasia during the Miocene?. Comptes Rendus Palevol, 7:383-390.

Rage, J.-C., Folie, A., Rana, R S., Singh, H., Rose, K.D. and Smith, T. 2008. A diverse snake fauna from the early Eocene of Vastan Lignite Mine, Gujarat, India. Acta Palaeontologica Polonica, 53:391-403.

Rage, J.-C. and Ginsburg, L. 1997. Amphibians and squamates from the early Miocene of Li Mae Long, Thailand: The richest and most diverse herpetofauna from the Cainozoic of Asia, p. 167-168. In Rocek, Z. and Hart, S. (eds.), Herpetology '97. Ministry of Environment of the Czech Republic, Prague.

Rage, J.-C. and Holman, J.A. 1984. Des serpents (Reptilia, Squamata) de type nord-américain dans le Miocène Français. Évolution parallèle ou dispersion?. Geobios, 17:89-104.

Rage, J.-C., Prasad, G.V., and Bajpai, S. 2004. Additional snakes from the uppermost Cretaceous (Maastrichtian) of India. Cretaceous Research, 25:425-434.

Rage, J.-C. and Werner, C. 1999. Mid-Cretaceous (Cenomanian) snakes from Wadi Abu Hashim, Sudan: The earliest snake assemblage. Palaeontologia Africana, 35:85-110.

Rage, J.-C. and Wouters, G. 1979. Découverte du plus ancien Palaeopheidé (Reptilia, Serpentes) dans le Maestrichtien du Maroc. Geobios, 12:293-296.

Rana, R.S., Kumar, K., Escarguel, G., Sahni, A., Rose, K.D., Smith, T., Singh, H., and Singh, L. 2008. An ailuravine rodent from the lower Eocene Cambay Formation at Vastan, western India, and its palaeobiogeographic implications. Acta Palaeontologica Polonica, 53:1-14.
Rose, K.D., DeLeon, V.B., Missiaen, P., Rana, R.S., Sahni, A., Singh, L., and Smith, T. 2008. Early Eocene lagomorph (Mammalia) from Western India and the early diversification of Lagomorpha. Proceedings of the Royal Society of London B, 275:1203-1208.

Roze, J. A. 1996. Coral snakes of the Americas: Biology, identification, and venoms. Krieger Publishing, Malabar, FI.

Salih, K.A.O., Evans, D.C., Bussert, R., Klein, N., Nafi, M., and Müller, J. 2015. First record of Hyposaurus (Dyrosauridae, Crocodyliformes) from the Upper Cretaceous Shendi Formation of Sudan. Journal of Vertebrate Paleontology, e1115408.

Sanders, K.L. and Lee, M.S. 2008. Molecular evidence for a rapid late-Miocene radiation of Australasian venomous snakes (Elapidae, Colubroidea). Molecular Phylogenetics and Evolution, 46:1165-1173.

Sanders, K.L., Lee, M.S.Y., Leys, R., Foster, R., and Keogh, J.S. 2008. Molecular phylogeny and divergence dates for Australian elapids and sea snakes (hydrophiinae): evidence from seven genes for rapid evolutionary radiations. Journal of Evolutionary Biology, 21:682-695.

Sanders, K.L., Mumpuni, Hamidy, A., Head, J.J., and Gower, D.J. 2010. Phylogeny and divergence times of filesnakes (Acrochordus): Inferences from morphology, fossils and three molecular loci. Molecular Phylogenetics and Evolution, 56:857-867.

Savitzky, A.H. 1980. The role of venom delivery strategies in snake evolution. Evolution, 34:1194-1204.

Scanlon, J.D., Lee, M.S.Y., and Archer, M. 2003. MidTertiary elapid snakes (Squamata, Colubroidea) from Riversleigh, northern Australia: early steps in a continent-wide adaptive radiation. Geobios, 36:573-601.

Schrank, E. 1990. Palynology of the clastic Cretaceous sediments between Dongola and Wadi Muqaddam, northern Sudan. Berliner Geowissenschaftliche Abhandlungen, Reihe A, 120:149-168.

Schrank, E. and Awad, M.Z. 1990. Palynological evidence for the age and depositional environment of the Cretaceous Omdurman Formation in the Khartoum area, Sudan. Berliner Geowissenschaftliche Abhandlungen, Reihe A, 120:169-182.

Sen, S. 1997. Magnetostratigraphic calibration of the European Neogene mammal chronology. Palaeogeography, Palaeoclimatology, Palaeoecology, 133:181-204.

Sheil, C.A. and Grant, T. 2001. A new species of colubrid snake (Synophis) from western Colombia. Journal of Herpetology, 35:204-209.

Slowinski, J.B. 1994. A phylogenetic analysis of Bungarus (Elapidae) based on morphological characters. Journal of Herpetology, 28:440-446.

Smith, M.J. 1975. The vertebrae of 4 Australian elapid snakes (Squamata: Elapidae). Transactions of the Royal Society of South Australia, 99:71-84. 
Smith, M.J. 1976. Small fossil vertebrates from Victoria Cave, Naracoorte, South Australia. IV. Reptiles. Transactions of the Royal Society of South Australia, 100:39-51.

Szyndlar, Z. 1984. Fossil snakes from Poland. Acta Zoologica Cracoviensia, 28:1-156.

Szyndlar, Z. 1985. Ophidian fauna (Reptilia, Serpentes) from the uppermost Miocene of Algora (Spain). Estudios Geologicos, 41:447-465.

Szyndlar, Z. 1987. Snakes from the lower Miocene locality of Dolnice (Czechoslovakia). Journal of Vertebrate Paleontology, 7:55-71.

Szyndlar, Z. 1988. Two new extinct species of the genera Malpolon and Vipera (Reptilia, Serpentes) from the Pliocene of Layna (Spain). Acta Zoologica Cracoviensia, 31:687-706.

Szyndlar, Z. 1991a. A review of Neogene and Quaternary snakes of central and eastern Europe. Part I: Scolecophidia, Boidae, Colubrinae. Estudios Geologicos, 47:103-126.

Szyndlar, Z. 1991b. A review of Neogene and Quaternary snakes of central and eastern Europe. Part II: Natricinae, Elapidae, Viperidae. Estudios Geologicos, 47:237-266.

Szyndlar, Z. 1992. Osteology of African cobras: preliminary observations, p. 425-428. In Korsós, Z. and Kiss, I. (eds.), Proceedings of the Sixth Ordinary General Meeting of the Societas Europaea Herpetologica. Hungarian Natural History Museum, Budapest.

Szyndlar, Z. 1994. Oligocene snakes of southern Germany. Journal of Vertebrate Paleontology, 14:24-37.

Szyndlar, Z. 2009a. Snake fauna (Reptilia: Serpentes) from the Early/Middle Miocene of Sandelzhausen and Rothenstein 13 (Germany). Paläontologische Zeitschrift, 83:55-66.

Szyndlar, Z. 2009b. The snakes (Reptilia, Serpentes) of the Miocene of Portugal. Ciencias da Terra, 14.

Szyndlar, Z. 2012. Early Oligocene to Pliocene Colubridae of Europe: a review. Bulletin de la Société Géologique de France, 183:661-681.

Szyndlar, Z. and Rage, J.C. 1990. West Palearctic cobras of the genus Naja (Serpentes: Elapidae): interrelationships among extinct and extant species. Amphibia-Reptilia, 11:385-400.

Szyndlar, Z. and Rage, J.-C. 1999. Oldest fossil vipers (Serpentes: Viperidae) from the Old World. Kaupia. Darmstädter Beiträge zur Naturgeschichte, 8:9-20.

Szyndlar, Z. and Rage, J.-C. 2002. Fossil record of the true vipers, p. 419-444. In Schuett, G.W., Höggren, M., Douglas, M.E., and Greene, H.W. (eds.), Biology of the Vipers. Eagle Mountain Publishing, Utah.

Szyndlar, Z. and Schleich, H.H. 1993. Description of Miocene snakes from Petersbuch 2 with comments on the lower and middle Miocene ophidian faunas of southern Germany. Stuttgarter Beitrage zur Naturkunde, Series B. Geologie und Palaontologie, 192:1-47.
Szyndlar Z., Smith, R., and Rage, J.-C. 2008. A new dwarf boa (Serpentes, Booidea, "Tropidophiidae") from the Early Oligocene of Belgium: a case of the isolation of Western European snake faunas. Zoological Journal of the Linnaean Society, 152:393-406.

Tedford, R H., Albright, B. III, Barnosky, A.D., Ferrusquia-Villafranca, I., Hunt, R.M. jr., Storer, J.E., Swisher, C.C. III, Voorhies, M.R., Webb, S.D., and Whistler, D.P. 2004. Mammalian Biochronology of the Arikareean Through Hemphillian Interval (Late Oligocene Through Early Pliocene Epochs), p. 169-231. In Woodburne, M.O. (ed.), Late Cretaceous and Cenozoic Mammals of North America: Biostratigraphy and Geochronology. Columbia University Press, New York.

Tucker, S.T., Otto, R.E., Joeckel, R.M., and Voorhies, M.R. 2014. The geology and paleontology of Ashfall Fossil Beds, a late Miocene (Clarendonian) massdeath assemblage, Antelope Country and adjacent Knox Country, Nebraska, USA. GSA Field Guides, 36:1-22.

Vandenberghe, N., Hilgen, F.J., and Speijer, R.P. 2012. The Paleogene Period, p. 855-921. In Gradstein, F., Ogg, J., Schmitz, M., and Ogg, G. (eds.), The Geologic Time Scale 2012. Elsevier Press.

Venczel, M. 2011. Middle-Late Miocene snakes from the Pannonian Basin. Acta Palaeontologica Romaniae, 7:343-349.

Vidal, N. 2002. Colubroid systematics: evidence for an early appearance of the venom apparatus followed by extensive evolutionary tinkering. Toxin Reviews, 21:21-41.

Vidal, N., Delmas, A.S., David, P., Cruaud, C., Couloux, A., and Hedges, S.B. 2007. The phylogeny and classification of caenophidian snakes inferred from seven nuclear protein-coding genes. Comptes Rendus Biologies, 330:182-187.

Vidal, N., Dewynter, M., and Gower, D.J. 2010. Dissecting the major American snake radiation: a molecular phylogeny of the Dipsadidae Bonaparte (Serpentes, Caenophidia). Comptes Rendus Biologies, 333:4855.

Vidal, N., Lecointre, G., Vie, J.C., and Gasc, J.P. 1999. What can mitochondrial gene sequences tell us about intergeneric relationships of pitvipers. Kaupia, 8:107-112.

Wallach, V., Williams, K.L., and Boundy, J. 2014. Snakes of the World: A catalogue of living and extinct species. CRC Press.

Wallach, V., Wüster, W., and Broadley, D.G. 2009. In praise of subgenera: taxonomic status of cobras of the genus Naja Laurenti (Serpentes: Elapidae). Zootaxa, 2236:26-36.

West, R.M., Hutchison, J.H., and Munthe, J. 1991. Miocene vertebrates from the Siwalik Group, western Nepal. Journal of Vertebrate Paleontology, 11:108129. 
Whistler, D.P. and Wright, J.W. 1989. A late Miocene rear-fanged colubrid snake from California with comments on the phylogeny of North American snakes. Herpetologica, 45:350-367.

Woodhead, J., Hand, S.J., Archer, M., Graham, I., Sniderman, K., Arena, D.A., Black, K.H., Godthelp, H., Creaser, P., and Price, E. 2016. Developing a radiometrically-dated chronologic sequence for Neogene biotic change in Australia, from the Riversleigh World Heritage Area of Queensland. Gondwana Research, 29:153-167.

Wüster, W., Crookes, S., Ineich, I., Mané, Y., Pook, C.E., Trape, J.F., and Broadley, D.G. 2007. The phylogeny of cobras inferred from mitochondrial DNA sequences: evolution of venom spitting and the phylogeography of the African spitting cobras (Serpentes: Elapidae: Naja nigricollis complex). Molecular Phylogenetics and Evolution, 45:43-453.
Wüster, W., Peppin, L., Pook, C.E., and Walker, D.E. 2008. A nesting of vipers: phylogeny and historical biogeography of the Viperidae (Squamata: Serpentes). Molecular Phylogenetics and Evolution, 49:445-459.

Zaher, H., Grazziotin, F.G., Cadle, J.E., Murphy, R.W., Moura-Leite, J.C.D., and Bonatto, S.L. 2009. Molecular phylogeny of advanced snakes (Serpentes, Caenophidia) with an emphasis on South American Xenodontines: a revised classification and descriptions of new taxa. Papéis Avulsos de Zoologia (São Paulo), 49:115-153. 